\title{
MODEL KEBIJAKAN PENINGKATAN LAPORAN KEMATIAN DALAM ADMINISTRASI KEPENDUDUKAN DAN CATATAN SIPIL DI KABUPATEN BANDUNG BARAT
}

\author{
Achdiat dan Yaya Mulyana \\ Fakultas Ilmu Sosial dan Ilmu Politik Universitas Pasundan Bandung \\ E-mail: dos_achdiat@yahoo.co.id
}

\begin{abstract}
ABSTRAK. Salah satu persoalan yang cukup pelik dalam Administrasi Kependudukan adalah yang berkaitan dengan Pencatatan Peristiwa Kematian. Kematian seseorang merupakan peristiwa hukum yang bukan perbuatan subjek hukum, akan tetapi akibatnya diatur oleh hukum. Akibat hukum yang timbul dari kematian seseorang adalah penentuan ahli waris, pembagian harta peninggalan dan perwalian. Untuk adanya tertib hukum guna melindungi hak-hak dan kewajiban ahli waris dan harta kekayaan yang ditinggalkan pewaris diperlukan regulasi mengenai peristiwa kematian tersebut. Pelaporan mengenai peristiwa kematian seseorang sangat diperlukan untuk pemeliharaan data kependudukan sehingga data yang tersaji merupakan data yang faktual. Kenyataan menunjukkan akibat tidak terekamnya data kependudukan, berkaitan dengan laporan kematian pada Dinas Kependudukan dan Pencatatan Sipil, menjadi masalah karena data kependudukan tidak valid. Gambaran aktual pencatatan akta kematian di Kabupaten Bandung Barat masih rendah, indikasinya terlihat dari permohonan penerbitan surat kutipan akta kematian pada Tahun 2015 hanya sebanyak 20 pemohon. Penelitian ini menemukan model kebijakan pencatatan akta kematian untuk meningkatkan kuantitas pencatatan akta kematian di Kabupaten Bandung Barat, berdasarkan SPM 70 \% pada Tahun 2018, dengan menggunakan pendekatan model inkrimentalisme.
\end{abstract}

Kata Kunci: Model Kebijakan, Laporan Akta Kematian, Tertib Administrasi

\section{POLICY MODEL OF IMPROVING DEATH REPORT IN POPULATION ADMINISTRATION AND CIVIL REVIEWS IN WEST BANDUNG REGENCY}

\begin{abstract}
One of the more complicated issues in the Population Administration is that related to Death Record. A person's death is a legal event that is not an act of legal subject but consequently governed by law. For the existence of legal order in order to protect the rights and obligations of the heirs and assets left by the heirs it is necessary regulation concerning the event of death. Reporting on the death of a person is very necessary for the maintenance of population data so that the data presented is factual data. The facts show the effect of unrecorded population data, relating to Death, becomes problematic because the data is invalid. The portrait of death certificate in West Bandung regency is still low, the indication is seen from the request for the issuance of death certificate document to the 2015 only 20 applicant. This research finds the model of death note registration policy to increase the quantity of death certificate registration in West Bandung regency, based on SPM $70 \%$ using incrementalism model approach.
\end{abstract}

Key Word: Policy Model, Death Certificate Report, Orderly Administration

\section{PENDAHULUAN}

Pembangunan Administrasi Kependudukan dan Pencatatan Sipil di Indonesia sebagai negara terbesar ke empatdarijumlahpenduduksetelah China, IndiadanUSA, memiliki peran strategis dalam Pembangunan Nasional, sehingga dalam rangka aktualisasi dan akurasi data serta kelengkapan kepemilikan dokumen kependudukan dan legalitas catatan sipil diperlukan pengelolaan administrasi kependudukan yang akurat, terkini dan dikelola secara komprehensif untuk mempercepat peningkatan kesejahteraan masyarakat. Oleh karena itu, Saefullah (2008): 138) menyatakan: Masalah kependudukan adalah masalah yang akan selalu dihadapi dalam pembangunan selama tingkat kesejahteraan penduduk belum merata secara layak, baik menyangkut kuantitas yang harus diatur dan ditata dengan benar, dan juga menyangkut kualitas yang dapat mengukur tingkat kehidupan suatu bangsa.

Merujuk pada Pasal 26 Ayat (3) UndangUndang Dasar Republik Indonesia Tahun 1945 yang telah mengamanatkan, bahwa "Hal-hal Warga Negara dan Penduduk diatur dengan Undang-Undang", yang ditindaklanjuti dengan Undang-Undang Nomor 23 Tahun 2006 tentang Administrasi Kependudukan yang direvisi oleh UU No. 24 Tahun 2013 dan seperangkat peraturan pelaksanaanya, antara lain Peraturan Presiden Nomor 26 Tahun 2009 tentang Penerapan Kartu Tanda Penduduk (KTP) Berbasis Nomor Induk Kependudukan (NIK), sebagaimana telah diubah dengan Peraturan Pemerintah Nomor 34 tahun 2010. Untuk itu, Pemerintah dengan dukungan DPR RI telah menetapkan program strategis yang merupakan reformasi mendasar di bidang kependudukan dan pencatatan sipil dengan cara merubah pola pikir (mindset) dari aparat dan masyarakat. Hal ini, sejalan dengan pemikiran Faturochman (2004:4): Isu dan masalah kependudukan yang dihadapi Indonesia, telah mendorong terjadinya perubahan paradigma kebijakan kependudukan secara mendasar, menyangkut kompleksitas dan dinamika kependudukan serta pengaruhnya terhadap isu kependudukan pada masa 
mendatang. Oleh karena itu, memerlukan adanya integrasi kebijakan pembangunan yang diarahkan untuk mengendalikan kuantitas dan meningkatkan kualitas penduduk.

Sehubungan hal di atas, dalam rangka memberikan jaminan status hukum perdata bagi penduduknya, penyediaan data kependudukan yang akurat guna mensukseskan Pemilu dan Pemilukada, penyediaan data statistik yang valid untuk perencanaan diberbagai bidang pembangunan, maka pembangunan Administrasi Kependudukan merupakan tugas besar dan menjadi tanggung jawab bersama antara Pemerintah Pusat, Pemerintah Propinsi dan Pemerintah Kabupaten/Kota secara terkoordinasi, konsisten dan berkesinambungan. Namun demikian, salah satu persoalan yang cukup pelik dalam Administrasi Kependudukan adalah yang berkaitan dengan Pencatatan Peristiwa Kematian. Kematian seseorang merupakan peristiwa hukum yang bukan perbuatan subjek hukum akan tetapi akibatnya diatur oleh hukum. Akibat hukum yang timbul dari kematian seseorang adalah penentuan ahli waris, pembagian harta peninggalan dan perwalian.

Untuk adanya tertib hukum guna melindungi hak-hak dan kewajiban ahli waris dan harta kekayaan yang ditinggalkan pewaris diperlukan regulasi mengenai peristiwa kematian tersebut. Di samping itu, pelaporan mengenai peristiwa kematian seseorang sangat diperlukan untuk pemeliharaan data kependudukan, sehingga data yang tersaji merupakan data yang faktual. Tetapi kenyataan menunjukkan, akibat tidak terekamnya data kependudukan, berkaitan dengan Kematian pada Dinas Kependudukan dan Pencatatan Sipil, menjadi kendala dalam validitas penentuan Data Pemilih Tetap (DPT) dalam pemilu, termasuk juga dalam program peningkatan kesejahteraan dan bantuan sosial, seperti halnya, program penanggulangan krisis ekonomi dan jaring pengaman sosial. Sumodiningrat (1999:121): Jaring pengaman sosial merupakan instrument yang memadukan program pembangunan khusus menanggulangi keadaan krisis (crash program) dan program pembangunan reguler menanggulangi masalah kesenjangan, kemiskinan, dan ketertinggalan. Adapun bentuk programnya berupa Bantuan Langsung Tunai (BLT) atau Bantuan Langsung Masyarakat Sementara (BLSM), pembagian beras miskin (Raskin). Namun demikian, kecenderungannya seringkali kurang tepat sasaran, karena subjek penerima program bantuan tidak faktual, akibat masih menggunakan data kependudukan yang telah kadaluarsa.

Demikian pula, persoalan sampai saat ini, berkaitan dengan pencatatan peristiwa kematian di Dinas Kependudukan dan Pencatatan Sipil Kabupaten Bandung Barat hanya rata-rata 20 pencatatan pertahun. Padahal biaya untuk mengurus akta kematian ini hanya Rp 20.000,00. Oleh karena itu, sepertinya untuk mencapai target PAD dari pembuatan Akta Kematian akan sulit, sebab minat masyarakat dalam pembuatan Akta Kematian masih sangat rendah, dalam sebulan paling banyak hanya dua orang yang mengajukan. Hal ini, sesuai dengan apa yang disampaikan oleh Kepala Bidang Catatan Sipil Disdukcasip KBB, Toteng Rizwan di Batujajar (Galamedia,14/7/2015). Jika pemohon Akta Kelahiran sampai ratusan orang per hari sementara kondisi terbalik justru terjadi untuk pemohon Akta Kematian. Persoalan ini tentunya urgen untuk diteliti secara mendalam, apakah peraturan perundangan yang tidak efektif atau kesadaran hukum masyarakat yang kurang, atau juga birokrasi yang tidak aktif melakukan penyuluhan dan sosialisasi program.

Berdasarkan latar belakang di atas, maka rumusan masalah penelitian ini adalah: "Bagaimana model kebijakan yang efektif untuk meningkatkan pelaporan pencatatan kematian dan penerbitan Kutipan Akta Kematian di Kabupaten Bandung Barat ?". Adapun pertanyaan penelitiannya, adalah: (1) Bagaimana potret eksisting proses Pelaporan Pencatatan Kematian di Kabupaten Bandung Barat ? (2) Bagaimana solusi untuk pencapaian SPM Penerbitan Kutipan Akta Kematian 70\% pada Tahun 2020 ? (3) Bagaimana model kebijakan yang dapat meningkatkan kuantitas pelaporan pencatatan kematian dan penerbitan Kutipan Akta Kematian di Kabupaten Bandung Barat?

Tujuan Penelitian ini adalah: (1) Menggambarkan potret eksisting proses pencatatan Kutipan Akta Kematian di Kabupaten Bandung Barat; (2) Mengidentikasi solusi pencapaian SPM Kutipan AktaKematian 70\% pada Tahun 2020; (3) Merumuskan skenario kebijakan yang dapat meningkatkan kuantitas pencatatan Kutipan Akta Kematian di Kabupaten Bandung Barat.Adapun kegunaan penelitian ini diharapkan: (1) Secara teoritis penelitian ini dapat memberikan kontribusi ilmiah bagi kajian kebijakan, khususnya dalam meningkatkan efektivitas Administrasi Kependudukan dan Pelaporan Kutipan Akta Kematian. (2) Secara praktis, dapat dijadikan bahan rekomendasi kebijakan dalam peningkatan pencatatan Kutipan Akta Kematian di Kabupaten Bandung Barat.

\section{METODE}

Fokus penelitian ini untuk melihat, menggambarkan, menganalisis, mencatat dan mengiterpretasikan kondisi di Kabupaten Bandung Barat, berkaitan dengan implementasi Undang-Undang Nomor 23 Tahun 2006 tentang Administrasi Kependudukan, yang telah di ubah oleh Undang-Undang Nomor 24 Tahun 2013 (Lembaran Negara Republik Indonesia Tahun 2007 Nomor 80 dan Tambahan Lembaran Negara Republik Indonesia Nomor 4736). Regulasi ini merubah dari penanganan administrasi kependudukan yang bersifat pasif menjadi bersifat stelsel aktif. Khususnya mengenai Pasal 4 yang menyebutkan: setiap kematian wajib dilaporkan oleh keluarganya atau yang mewakilinya kepada Instansi Pelaksana paling lambat 30 (tiga puluh) hari sejak tanggal kematian. Sesuai dengan spirit stelsel aktif, maka peran 
RT/RW menjadi sentral dalam melaporkan peristiwa kematian dilingkungannya, ke jenjang pemerintahan di atasnya.

Penelitian ini menggunakan pendekatan kualitatif, dengan maksud untuk memahami makna dari fenomena dan masalah sosial yang sedang diteliti. Rancangan penelitian kualitatif menurut Crasswell (2014:4): "Merupakan metode-metode untuk mengeksplorasi dan memahami makna yang oleh sejumlah individu atau sekelompok orang, dianggap berasal dari masalah sosial atau kemanusiaan. Proses penelitian kualitatif ini melibatkan upaya-upaya penting, seperti mengajukan pertanyaan-pertanyaan dan prosedur-prosedur, mengumpulkan data yang spesifik dari para partisipan, menganalisis data secara induktif mulai dari tema-tema yang khusus ke tema-tema umum, dan menafsirkan makna data”. Sementara itu, Sugiyono (2008:1) mengatakan: "pendekatan kualitatif digunakan untuk meniliti pada kondisi objek yang alamiah di mana peneliti sebagai instrumen kunci, teknik pengumpulan data dilakukan secara triangulasi, analisis data bersifat induktif, hasil penelitiannya menekankan pada makna daripada generalisasi”.

Metode yang digunakan dalam penelitian ini adalah penelitian fenomenologi dengan tujuan untuk memberikan gambaran yang lebih detail mengenai suatu gejala atau fenomena yang sedang diteliti, berkaitan dengan model kebijakan peningkatan laporan kematian dalam administrasi kependudukan dan catatan sipil di Kabupaten Bandung Barat. Mengenai penelitian kualitatif dengan metode fenomenologis dijelaskan Moleong (2014:17) seperti berikut: "Penelitian fenomenologis berusaha memahami arti peristiwa dan kaitan-kaitannya terhadap orang-orang yang berada dalam situasi-situasi tertentu".

Jenis data yang dibutuhkan dalam penelitian ini mencakup data kuantitatif dan kualitatif. Berdasarkan sumber data, mencakup data primer dan data sekunder. Informan yang akan dijadikan sumber data primer, dan digali informasinya berkaitan dengan potret dan gambaran aktual pencatatan akta kematian di KBB akan dilakukan dengan Camat Cisarua, Camat Ngamprah, Camat Padalarang, dan Camat Gunung Halu. Selanjutnya, dengan Kepala Desa (Kades) Pasir Halang Kecamatan Cisarua, Kades Tani Mulya Kecamatan Ngamprah, Kades Kerta Mulya Kecamatan Padalarang, dan Kades Sirna Jaya Kecamatan Gunung Halu, sebagai representasi dari penyelenggara pelayanan administrasi kependudukan.

\section{HASIL DAN PEMBAHASAN}

Data pemohon akta kematian yang diperoleh dari Dinas Kependudukan dan Catatan Sipil (Disdukcapil) Kabupaten Bandung Barat (KBB), media data pada Tahun 2014 hingga akhir Bulan Mei Tahun 2015, dapat diketahui bahwa masyarakat yang mengajukan permohonan Kutipan Akta Kematian tercatat hanya sebanyak 20 orang pemohon. Berdasarkan hasil observasi diketahui rata-rata peristiwa kematian di setiap kecamatan perbulanya adalah antara lima (5) sampai delapan (8) orang. Sebagai bahan ilustrasi, bahwa KBB terdiri atas 17 Kecamatan dan 183 Desa. Bila jumlah rata-rata orang yang meninggal dikalikan dengan jumlah kecamatan dan dikalikan dengan tahun, maka yang mengajukan Kutipan Akta Kematian tidak mencapai angka sepuluh persen $(10 \%)$ dari jumlah peristiwa kematian yang terjadi di KBB.

Sementara itu, payung hukum yang berkaitan dengan mekanisme dan prosedur permohonan pengajuan Kutipan Akta Kematian yang dimulai dari laporan pemberitahuan kepada RT/RW, kemudian ke Desa dan Kecamatan, selanjutnya diajukan ke Disdukcapil KBB untuk diproses, tercantum dalam Perda KBB Nomor 15 Tahun 2011 Tentang Tata Cara Penyelenggaraan Pelayanan Administrasi Kependudukan. Oleh karena itu, persoalan penanganan laporan kematian ini perlu mendapat perhatian yang serius, sebagai upaya untuk pemutakhiran data kependudukan yang valid dan akurat.

Berdasarkan hasil wawancara pada hari Selasa tanggal 12 Mei Tahun 2015 dengan Sekretaris Disdukcapil yang pada saat itu sekaligus sedang menjabat PLT Sekdis Disdukcapil KBB, didapat keterangan bahwa persoalan pada umumnya berkaitan dengan tertib administrasi kependudukan di KBB, dan secara khusus menyangkut tentang laporan kematian dalam tertib administrasi kependudukan dan catatan sipil, dihadapkan pada tiga persoalan yang menyangkut tumpang tindih kebijakan, perbedaan data kependudukan, dan berkenaan dengan SDM Disdukcapil KBB.

Pertama, berkaitan dengan tumpang tindih kebijakan, sementara ini memang sulit untuk dipungkiri, bahwa di KBB dan juga termasuk di Kabupaten/Kota lainnya di seluruh Provinsi yang berada di Negara Indonesia, masih dihadapkan pada persoalan terjadinya tumpang tindih kebijakan kependudukan atara pemerintah pusat dan pemerintah daerah seperti UU Nomor 23 Tahun 2006 Tentang Administrasi Kependudukan. PP Nomor 38 Tahun 2007 Tentang Pembagian Urusan Pemerintah, Pemerintah Daerah Provinsi, Kabupaten/Kota. PP Nomor 41 Tahun 2007 Tentang Organisasi Perangkat Daerah. Sehingga, kondisi ini menjadi sulit bagi Disdukcapil untuk melaksanakan tugas dalam melaksanakan tertib administrasi kependudukan.

Kedua, berkenaan dengan persoalan mengenai tumpang tindihnya kebijakan dalam menjalankan roda pemerintahan daerah otonom, termasuk kebijakan tertib administrasi kependudukan atara pemerintah pusat dan pemerintah daerah, menyebabkan perbedaan data kependudukan di KBB, di mana ada data kependudukan yang dikeluarkan oleh Badan Pusat Statistik (BPS), kemudian dari Badan Koordinasi Keluarga Berencana Nasional (BKKBN), dan Kementerian Dalam Negeri 
(Kemendagri), yang versi dan acuannya menurut Sekretaris Disdukcapil berbeda.

Namun saat ini, Pemerintah KBB khususnya Disdukcapil memutuskan untuk menginduk pada data kependudukan yang dikeluarkan oleh Kemendagri, sebagai institusi yang memayungi pemerintahan daerah otonom, meskipun data dari kependudukan yang dikeluarkan oleh Kemendagri tersebut, sering menimbulkan konflik dengan masyarakat ketika pemilu (pileg, pilpres, pilkada, dan pildes), serta pada saat adanya program bantuan sosial dari pemerintah seperti bantuan subsidi akibat kenaikan BBM, Raskin, program Rehab Rumah Tidak Layak Huni (Rutilahu) bagi masyarakat tertentu, yang ditetapkan sebagai sasaran dari program pemerintah tersebut.

Ketiga, menyangkut persoalan faktor Sumberdaya Manusia (SDM) aparatus Disdukcapil KBB masih menjadi kendala, apalagi dikaitkan dengan kebijakan untuk meningkatkan Standar Pelayanan Minimal (SPM) sekitar 70\% pada tahun 2018, sesuai dalam Rencana Pembangunan Jangka Menengah (RPJM) 2013-2018 $\mathrm{KBB}$, secara kuantitatif, hal ini ditunjukkan oleh jumlah Pegawai Negeri Sipil (PNS) Disdukcapil KBB yang hanya tersedia sebanyak 24 orang pegawai, melihat kenyataan ini, nampaknya masih jauh dari harapan, untuk dapat mencapai SPM Disdukcapil sekitar $70 \%$ dalam hal tertib administrasi kependudukan, dan khususnya dalam meningkatkan Penerbitan Kutipan Akta Kematian pada Tahun 2018. Sementara itu, untuk mencapai jumlah ideal dibutuhkan sekitar 80 orang PNS untuk melayani masalah kependudukan di Kantor Disdukcapil KBB.

Adapun bagaimana prosedur dan mekanisme dalam penerbitan Kutipan Akta Kematian tersebut dijelaskan, bahwa prosesnya dimulai dari pemohon laporan kepada RT/RW setempat, sekaligus untuk mendapatkan Surat Pengantar/Serbaguna untuk permohonan penerbitan Surat Keterangan Kematian (SKK) di Kantor Desa, setelah mendapatkan SKK dari Kantor Desa selanjutnya dibawa ke Kantor Kecamatan untuk diproses, setelah diketahui oleh pihak Kecamatan (Camat), selanjutnya dibawa ke Disdukcapil KBB sebagai syarat untuk mengajukan permohonan penerbitan Surat Kutipan Akta Kematian. Terlebih lagi, pada saat ini, Kantor Disdukcapil telah menerbitkan dan membagikan kepada setiap RW berupa buku administrasi kependudukan dan catatan sipil, yang disebut dengan istilah buku keterangan Lampid (Lahir, Mati, pindah, Datang), untuk memudahkan pelayanan publik di bidang administrasi kepenudukan dan catatan sipil.

Data dan informasi berikutnya akan dikemukakan hasil observasi dan wawancara pada daerah kecamatan yang dijadikan sasaran penelitian. Adapun hasil observasi di empat kecamatan tersebut, baik di daerah kecamatan yang dianggap sebagai representasi dari daerah perkotaan yang sektor ekonominya lebih bertumpu pada jasa dan perdagangan, juga di daerah kecamatan yang sektor ekonominya bertumpu pada pertanian, dapat diketahui kondisinya relatif hampir sama, bahwasanya disetiap Seksi Pemerintahan yang salah satu tugas pokok dan fungsinya berkaitan dengan masalah administrasi kependudukan hampir tidak ditemukan aktivitas yang mengurus surat keterangan kematian, kecuali disibukan oleh kegiatan orang mengurus e-KTP.

Sementara hal-hal yang berkaitan dengan hukum keperdataan lainnya, kecenderungannya relatif kecil/ kurang, misalnya perihal bagi waris dapat diselesaikan secara musyawarah diantara keluarga, kecuali kalau harta warisnya akan dipindahtangankan kepada pihak ketiga, hal itupun dilakukan semata-mata keinginan pihak ketiga, apalagi pihak ketiganya berasal dari luar desa setempat. Terkecuali, jika orang yang meninggal itu memiliki profesi seperti karyawan, PNS, Guru, TNI/Polri, yang memiliki hak atas tunjangan kematian, pensiun, THT, urusan dengan Bank, dan sifat keperdataan lainnya, hanya cukup membuat surat keterangan laporan kematian dari pemerintah desa.

Padahal surat keterangan kematian tersebut bukan saja penting bagi pihak keluarga almarhum, tetapi juga, bagi pihak Pemerintah Kecamatan Ngamprah menganggap penting data yang valid, akurat, dan mutakhir berkaitan dengan kependudukan, terutama apabila dikaitkan dengan program-program pemerintah seperti dalam pelaksanaan pemilu (Pusat, Daerah, hingga Pildes). Begitu juga, data kependudukan yang valid, akurat, dan mutakhir sangat dibutuhkan, manakala ada rencana dan program-program pemerintah, seperti halnya, berkaitan dengan programprogram bantuan pemerintah (BLTSM), Raskin, dll.Pada saat pelaksanaannya, sering terjadi orang yang sudah meninggal masih tercantum sebagai penerima bantuan program pemerintah.

Kesulitan pemerintah kecamatan dan juga pemerintah desa dalam menentukan dan menetapkan orang-orang yang menjadi sasaran dari program pemerintah tersebut, lebih disebabkan oleh keberadaan data kependudukan tersebut. Adapun, mengenai data jumlah penduduk di Kabupaten Bandung Barat, saat ini ada tiga versi data kependudukan, seperti versi Badan Pusat statistik (BPS), kemudian versi yang diterbitkan oleh Badan Koordinasi Keluarga Berencana Nasional, dan versi yang ditetapkan Disdukcapil KBB, dari ketiga versi penyajian data kependudukan ini jumlahnya tidak sama.

Berdasarkan wawancara dengan Pelaksana Tugas Kepala Dinas/Sekretaris Disdukcapil Kabupaten Bandung Barat pada hari Selasa tanggal 12 Mei 2015, upaya yang akan dilakukan oleh Disdukcapil KBB dalam mencapai Standar Pelayanan Minimal (SPM) $70 \%$ pada tahun 2020, yang telah diamanatkan oleh PP No. 25/2005 tentang Pedoman dan Penyusunan SPM. Namun demikian, Disdukcapil KBB akan bertekad untuk dapat mencapai SPM sebesar $70 \%$, dalam rangka tertib administrasi kependudukan dan catatan sipil secara 
umum, dan secara khusus dalam peningkatan pencatatan akta kematian yang menghasilkan Data Base sebagai dasar Pencapaian SPM 70\%, maka sesuai dengan RPJM KBB 2013-2018 SPM tersebut harus dapat dicapai pada tahun 2018.

Solusi peningkatan pencatatan akta kematian yang menghasilkan data base sebagai dasar Pencapaian SPM Akta Kematian pada Tahun 2018 dan tertib administrasi kependudukan dan catatan sipil di Disdukcapil KBB, diantaranya melalui upaya sebagai berikut: Pertama, sosialisasi mengenai tertib administrasi kependudukan, terutama berkaitan dengan pentingnya pelaporan kematian dan membuat surat keterangan kematian di tingkat Pemerintahan Desa dan diketahui oleh Pemerintah Kecamatan, sampai pembuatan akta kematian di Dinas Kependudukan KBB. Kegiatan ini, telah dilaksanakan dengan melibatkan kader PKK se KBB pada bulan Desember 2014. Kedua, Pembinaan Teknis (Bintek) administrasi kependudukan Lahir, Mati, Pindah, dan Datang (Lampid) di tingkat RW di seluruh $\mathrm{KBB}$, yang telah dilaksanakan selama dua hari pada bulan April 2015. Kegiatan ini dilaksanakan dalam rangka menjawab Perubahan Penyelenggaraan Administrasi Kependudukan yang diamanatkan dalam UU No. 24 Tahun 2013.Sebagaimana diketahui bahwa Perubahan undang-undang tersebut lebih bersifat stelsel aktif, dalam kegiatan Bintek ini telah dibagikan pula sarana untuk menunjang pelayanan administrasi kependudukan berupa Buku Lampid.

Ketiga, perlu membentuk Unit Pelayanan Teknis Dinas (UPTD) Disdukcapil KBB, yang dapat ditempatkan disetiap wilayah yang dapat menangani dan mengkoordinasikan beberapa Kecamatan dalam melayani administrasi kependudukan.Adapun penentuan wilayah UPTD Disduk KBB dapat ditentukan melalui daerah pemilihan (Dapil) dalam pelaksanaan Pemilu di KBB.

Keempat, perlu perubahan kebijakan insentif yang lebih proporsional bagi para RT/RW, agar mau pro aktif dalam rangka melaksanakan tertib administrasi dan catatan sipil, termasuk pencatatan laporan kematian dengan mendatangi keluarga yang anggota keluarganya ada yang meninggal, sesuai perubahan peraturan perubahan perundang-undangan seperti tersebut di atas. Selama ini, insentif yang telah diberikan kepada RT sebesar 75 ribu rupiah perbulan, dan insentif kepada RW diberikan sebesar 100 ribu rupiah, yang dibayarkan setiap triwulan sekali. Besaran insentif ini, dirasakan tidak seimbang dengan tugas dan mobilitas yang diemban oleh RT/RW, apalagi, perubahan undang-undang kependudukan yang baru bersifat stelsel aktif, sehingga mengarahkan perangkat RT/RW untuk bertugas pro aktif.

Kelima, untuk menciptakan tertib administrasi kependudukan dan catatan sipil, telah diupayakan oleh Disdukcapil KBB dengan menempatkan empat (4) petugas Sukarelawan (Sukwan) di setiap Kecamatan.
Tugasnya, adalah untuk melayani pembuatan e-KTP dan KK, sejalan dengan bergulirnya program e-KTP. Tetapi, di tingkat Pemerintahan Desa belum ada petugas sukwan yang ditempatkan oleh Disduk, yang bertugas untuk menertibkan dan melayani administrasi kependudukan dan catatan sipil, termasuk untuk melakukan catatan laporan kematian. Keenam, perlu dilakukan koordinasi yang kontinyu antar instansi terkait dengan Pemerintahan Desa dan RT/RW berkaitan dengan administrasi kependudukan sesuai Buku Lampid, melalui sarana pembagian insentif RT/RW pertriwulan.

Ketujuh ,intinya dengan memberi motivasi dalam rangka mengoptimalkan peran, tugas dan fungsi perangkat RT dan RW, untuk meningkatkan laporan administrasi kependudukan dan catatan sipil, khususnya berkaitan dengan peningkatan laporan pembuatan surat kutipan akta kematian pada Disdukcapil KBB. Oleh karena itu, upaya untuk meningkatkan laporan kematian dalam rangka tertib administrasi kependudukan dan catatan sipil tersebut, maka kebijakan pemberian insentif kepada perangkat RT dan RW perlu segera direalisaikan.

Kedelapan, perlu segera diterbitkan peraturan daerah tentang tertib administrasi kependudukan dan catatan sipil sesuai perubahan peraturan perundangundangan baru yang bersifat stelsel aktif, sebagai payung hukum dalam rangka pelaksanaan tertib administrasi kependudukan dan catatan sipil di Kabupaten Bandung Barat. Perumusan peraturan daerah ini, didasarkan pada hasil kajian akademik sebagai dasar, dalam perumusan rancangan peraturan daerah (raperda) administrasi kependudukan dan catatan sipil di Kabupaten Bandung Barat.

Beberapa hasil penelitian sebelumnya, menunjukkan hal yang sama dalam menjawab berbagai persoalan yang berkaitan dengan pelaksanaan administrasi kependudukan. Hasil penelitian Nugraha (2009) menyimpulkan: 1) Pengembangan Sistem Informasi Kependudukan (SIAK) untuk mewujudkan pelayanan administrasi kependudukan dan catatan sipil, yang berorientasi pada kepuasan dan kemitraan masyarakat; 2) Pengembangan SIAK memberikan informasi yang cepat kepada masyarakat tentang pembuatan dokumen kependudukan; 3) Mewujudkan pelayanan administrasi kependudukan dan catatn sipil yang beorientasi pada kepuasan dan kemitraan masyarakat menuju terciptanya data dan informasi kependudukan yang akurat. Hasil penelitian Insani (2010) menyimpulkan: 1) Dibutuhkan sosialisasi kepada aparatur pemerintah terkait, sebagai pelaksana kebijakan administrasi kependudukan, dan kepada masyarakat mengenai hak dan kewajiban penduduk dalam administrasi kependudukan. 2) Dalam rangka mendukung suksesnya Sistem Informasi Kependudukan (SIAK) on-line maka diperlukan: (a) Komitmen bersama yang dituangkan dalam peraturan pelaksanaan (Permen, Perda, Keputusan Kepala Daerah); (b) Pelatihan tenaga operator SIAK dan atau 
menyediakan tenaga operator yang handal; (c) Penelitian dan pengembangan SIAK yang disesuaikan dengan kondisi daerah setempat. Berikutnya kesimpulan hasil penelitian Rachmawati (2012) adalah: 1) perlu peningkatan pembelajaran dalam mengembangkan kemampuan sumberdaya aparatur, berkaitan dengan pelayanan administrasi kependudukan yang efektif; 2) Upaya untuk merealisasikan pembelajaran aparatur tidak memerlukan biaya yang besar, namun aparatur harus mempunyai kemauan diri yang kuat untuk mendapatkan pengetahuan baru, baik dari dalam maupun dari luar lingkungan tempat kerja.

Beberapa pertimbangan di atas, selanjutnya akan dibandingkan dengan informasi dari pihak kecamatan yang dijadikan informan, ternyata pandangan dari pihak kecamatan tidak jauh berbeda dengan pertimbangan dari pihak Disdukcapil KBB, bahwa diperlukan segera mungkin mengaktifkan perangkat RT/RW sesuai perubahan peraturan perundang-undangan yang baru yang bersifat stelsel aktif. Sehingga persoalan administrasi kependudukan dan catatan sipil dapat ditata ulang untuk mendapatkan jumlah penduduk yang valid dan akurat.

Selain hal tersebut di atas, perlu adanya peninjauan kembali mengenai kebijakan besaran insentif yang diberikan kepada pihak RT/RW, agar supaya bisa lebih meningkatkan motivasi kerjanya yang tinggi dan pro aktif apabila terjadi peristiwa kematian. Di samping itu juga, sangat dibutuhkan kontinuitas Pembinaan Teknis (Bintek) bagi peserta yang sama, yang telah mengikuti pembinaan teknis sebelumnya berkaitan dengan administrasi kependudukan dan catatan sipil, sehingga para peserta pembinaan teknis lebih mengerti dan memahami bagaimana administrasi kependudukan itu dilakukan berdasarkan perubahan peraturan perundang-undangan yang baru dan berdasarkan Buku Induk Lampid yang telah disediakan dan dibagikan oleh Disdukcapil KBB kepada pihak RT/RW.

Merujuk pada hasil pembahasan mengenai potret dan gambaran aktual pencatatan akta kematian di Kabupaten Bandung Barat, serta upaya-upaya yang telah dilakukan oleh Disdukcapil KBB, sebagai solusi dalam rangka peningkatan pencatatan akta kematian, yang diharapkan dapat menghasilkan data base sebagai dasar Pencapaian SPM Akta Kematian pada Tahun 2018 sesuai RPJM KBB 2013-2018. Maka dengan demikian, model yang cocok untuk digunakan dalam mencapai SPM 2018 pada konteks peningkatan kuantitas pencatatan akta kematian, dengan menggunakan pendekatan model inkrimentalisme (incrementalism).

Simon (Islamy, 1994:64) menjelaskan: Model inkremental ini memandang kebijakan negara sebagai suatu kelanjutan kegiatan-kegiatan pemerintah di masa lalu dengan hanya mengubahnya (modifikasi) sedikitsedikit. Selanjutnya, Thoha (2008:145) menegaskan:
Model kebijakan inkrementalisme perhatiannya terhadap program baru dipusatkan untuk menambah, mengurangi, dan menyempurnakan program-program yang telah ada. Pembuat policy pada umumnya menerima keabsahan (legitimacy) dari program-program yang telah ditetapkan dan menyetujui untuk melanjutkan policy-policy yang sudah ada sebelumnya. Jadi yang menjadi landasannya adalah pada evaluasi dan analisa empiris terhadap program-program, kebijakan-kebijakan negara yang telah dilaksanakan sebelumnya, dengan menambah, mengurangi, memodifikasi sedikit program-program, kebijakan-kebijakan, pengeluaran-pengeluaran negara untuk dasar pembuatan keputusan-keputusan yang baru.

Berdasarkan pendekatan model inkrimental ini, selanjutnya tim peneliti merumuskan model kebijakan, sebagai bahan pertimbangan untuk dijadikan landasan dalam memodifikasi kebijakan sebelumnya, berkaitan dengan upaya untuk meningkatkan kuantitas pencatatan akta kematian di KBB. Pertimbangan untuk memodifikasi kebijakan peningkatan kuantitas pencatatan akta kematian di $\mathrm{KBB}$, didasarkan atas hasil penelitian yang telah dilakukan di KBB pada tahun 2015. Adapun beberapa landasan yang dapat dijadikan pertimbangan untuk memodifikasi kebijakan KBB, dalam meningkatkan kuantitas pencatatan akta kematian sebagai berikut: (1) Aspek Yuridis meliputi UU No.23/2006; PP No. 34/2010 ; Permendagri No. 28/2005; Permendagri No. 69/2012. (2) Aspek Teoritis mengacu pada Konsep Administrasi Negara; Konsep Kependudukan dan Catatan Sipil; Konsep Kebijakan Publik (Negara). (3) Aspek Empiris berkaitan dengan data dan informasi faktual hasil observasi dan wawancara di lapangan. (4) Naskah Akademik hasil penelitian "Model Kebijakan Publik Untuk meningkatkan Laporan Kematian Dalam Tertib Administrasi Kependudukan Dan Catatan Sipil Di Kabupaten Bandung Barat. (5) Raperda Kependudukan dan Catatan Sipil KBB, berdasarkan naskah akademik dirumuskan rancangan peraturan daerah kependudukan dan catatan sipil KBB yang bersifat stelsel aktif, dalam meningkatkan pencatatan akta kematian di wilayah KBB. Raperda selanjutnya diajukan ke DPRD KBB, (6) Perda Kependudukan dan Catatan Sipil KBB yang bersifat stelsel aktif, sebagai landasan hukum dalam meningkatkan pencatatan akta kematian di wilayah KBB. (7) Sarana berupa Kantor UPTD Kependudukan dan Catatan Sipil KBB pada setiap wilayah bisa disesuaikan dengan Dapil. Hardware dan Software.Sistem Administrasi Kependudukan dan catatan Sipil KBB. Buku Induk Kependudukan dan Catatan Sipil (Lampid). (8) Kelembagaan, dibentuknya UPTD Kependudukan dan Catatan Sipil, dengan tugas pokok dan fungsi membantu sebagian tugas dari Kepala Disdukcapil. Menjadi koordinator di wilayah kerjanya berkaitan dengan 


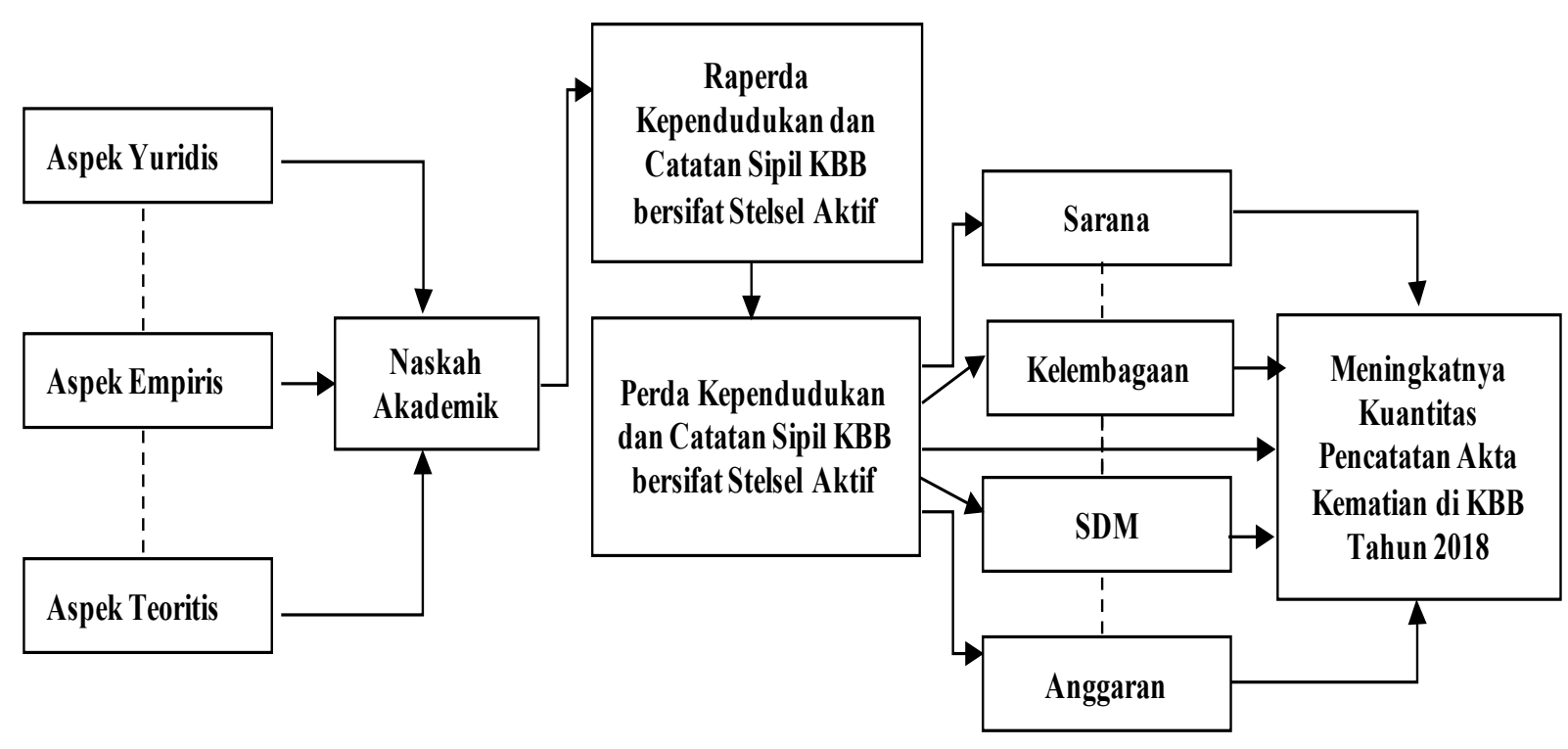

Gambar 1: Model Kebijakan Pencatatan Akta Kematian di KBB

tertib administrasi kependudukan dan catatan sipil, termasuk pelaporan peristiwa kematian. (9) SDM Disdukcapil PNS dan/atau Tenaga Sukarelawan yang telah dilatih dan dibina dalam melayani tugas di bidang administrasi kependudukan dan catatan sipil, termasuk tugas dalam mencatat peristiwa kematian. PNS dan/atau Tenaga Sukarelawan ini ditempatkan di Kantor UPTD Kependudukan dan Catatan Sipil dan di Kantor Kecamatan. PNS dan/atau Tenaga Sukarelawan ini dapat membina di tingkat desa dan RT/RW dalam mengaplikasikan Buku Induk Lampid. (10) Anggaran: Perlu peningkatan anggaran untuk mendudung SPM Disdukcapil KBB, dalam rangka meningkatkan tertib administrasi kependudukan dan catatan sipil pada tahun 2018.

Peningkatan besaran insentif RT/RW sebagai ujung tombak dalam rangka meningkatkan pelayanan kependudukan dan catatan sipil, termasuk untuk melayani laporan peristiwa kematian, sesuai Peraturan Daerah KBB tentang Kependudukan dan Catatan Sipil yang bersifat Stelsel Aktif. Langkas-langkah Seperti itu sesuai dengan yang dikatakan Moynihan dan Ingram (2001) dalam Kurniasih (2011) bahwa pemerintahan dengan kapasitas manajemen yang tinggi akan menghasilkan kinerja yang lebih baik. Dimana kapasitas manajemen merupakan pra kondisi bagi kinerja sehingga di dalamnya juga mengaitkan aspek-aspek organisasi, sumber daya aparatur, keuangan, struktur dan kepemimpinan

Bagaimana pentingnya suatu model kebijakan dalamkonteks penelitian ini, dijelaskan Parsons(2005:59): Dalam menganalisis kebijakan publik kita harus bisa mengorganisasikan ide-ide dan konsep. Dunia adalah sebuah tempat yang kompleks, dan untuk memahami kompleksitas ini kita perlu penyederhanaan, dalam rangka memahami multiplisitas faktor dan kekuatan yang membentuk problem dan proses sosial, dengan menyusun model-model, pemetaan (map), atau berpikir dalam term metafora. Sementara itu, Tachjan (2008:36) menjelaskan: model merupakan suatu kerangka pemikiran tertentu yang akan memberikan gambaran kepada kita secara bulat lengkap mengenai sesuatu obyek, situasi, atau proses. Komponen-komponen apa saja yang terdapat pada objek, situasi, atau proses tersebut. Bagaimana korelasi-korelasinya antara komponen-komponen itu satu dengan yang lainnya.

Oleh karena itu, salah satu out put yang ingin dihasilkan dari penelitian ini adalah ditemukannya model kebijakan peningkatan laporan kematian dalam administrasi kependudukan dan catatan sipil di Kabupaten Bandung Barat. Adapun visualisasi model kebijakan publik untuk meningkatkan laporan kematian dalam tertib administrasi kependudukan dan catatan sipil di Kabupaten Bandung Barat, digambarkan pada Gambar 1.

\section{SIMPULAN}

Potret dan gambaran aktual pencatatan laporan akta kematian dalam tertib administrasi kependudukan dan catatan sipil di Kabupaten Bandung Barat masih rendah, indikasinya terlihat dari permohonan penerbitan surat kutipan akta kematian pada Dinas Kependudukan dan Catatan Sipil, pada Tahun 2014 hingga akhir Bulan Mei Tahun 2015 tidak sampai angka sepuluh persen (10\%) dari jumlah peristiwa kematian yang terjadi di KBB.

Solusi peningkatan pencatatan akta kematian yang menghasilkan data base sebagai dasar Pencapaian SPM akta kematian pada Tahun 2020, telah dilakukan melalui upaya-upaya: (1) Sosialisasi terhadap kader PKK se KBB pada bulan Desember 2014. (2) PembinaanTeknis (Bintek) administrasi kependudukan Lahir, Mati, Pindah, dan Datang (Lampid) di tingkat RW di seluruh KBB; (3) Perlu membentuk Unit Pelayanan Teknis Dinas (UPTD) Disdukcapil KBB, yang ditempatkan disetiap wilayah dalam mengkoordinasikan beberapa Kecamatan 
dalam melayani administrasi kependudukan; (4) Perlu perubahan kebijakan insentif yang lebih proporsional bagi para RT/RW, agar mau pro aktif khususnya dalam melaksanakan pencatatan laporan kematian; (5) Disdukcapil KBB telah menempatkan empat (4) petugas Sukarelawan (Sukwan) di setiap kecamatan, untuk melayani pembuatan E-KTP dan KK; (6) Perlu dilakukan koordinasi yang kontinyu antar instansi terkait dengan Pemerintahan Desa dan RT/RW berkaitan dengan administrasi kependudukan sesuai Buku Induk Lampid, melalui sarana pembagian insentif RT/RW pertriwulan; (7) Memberi motivasi dalam rangka mengoptimalkan peran, tugas dan fungsi perangkat RT/RW, dalam peningkatan laporan pembuatan suratkutipan akta kematian pada Disdukcapil KBB; (8) Perlu segera diterbitkan peraturan daerah tentang tertib administrasi kependudukan dan catatan sipil sesuai perubahan peraturan perundang-undangan baru yang bersifat stelsel aktif, sebagai payung hukum dalam rangka peningkatan laporan kematian di Kabupaten Bandung Barat.

Model kebijakan pencatatan akta kematian untuk meningkatkan kuantitas pencatatan akta kematian di KBB, berdasarkan SPM 70 \% pada Tahun 2018 sesuai RPJM KBB 2013-2018, dengan pendekatan model inkrimental dengan cara memodifikasi kebijakan lama. Pertimbangan untuk memodifikasi kebijakan KBB dalam meningkatkan kuantitas pencatatan akta kematian : (1) Aspek Yuridis; (2) Aspek Teoritis; (3) Aspek Empiris; (4) Naskah Akademik (Hasil penelitiantahun 2015); (5) Raperda Kependudukan dan Catatan Sipil KBB; (6) Perda Kependudukan dan Catatan Sipil KBB yang bersifat stelsel aktif, sebagai landasan hukum dalam meningkatkan pencatatan akta kematian di wilayah KBB; (7). Sarana; (8) Kelembagaan; (9) Sumber Daya Manusia; (10) Anggaran.

\section{DAFTAR PUSTAKA}

Crasswell, J.W. 2014. Research Design. Pendekatan Kualitatif, Kuantitatif, dan Mixed. Edisi Ketiga Terjemahan Achmad Fawaid. Yogyakarta: Pustaka Pelajar.

Faturochman dan Wicaksono, B. 2004. Dinamika Kependudukan Dan Kebijakan. Yogyakarta: Pusat Studi Kependudukan dan Kebijakan Universitas Gadjah Mada.

Galamedia. 2015. Regulasi Administrasi Kependudukan tentang Kematian di Kabupaten Bandung Barat. Galamedia, Terbitan 14/7/2015.

Insani, I. 2010. Implementasi Kebijakan Administrasi Kependudukan di Kota Banda Aceh Provinsi Nanggroe Aceh Darussalam, diakses 18-052015 dari http://www.stialan.ac.id/artikel/ artikel\%20istyadi.pdf.
Islamy, I. 1994. Prinsip-Prinsip Perumusan Kebijaksanaan Negara. Jakarta: Bumi Aksara

Kurniasih, D. 2011. Kinerja Program Kesehatan Dalam ,menjangkau Masyarakat Miskin: Studi Tentang Kapasitas Manajemen Dalam Program Jaminan Kesehatan Masyarakat (Jamkesmas) Untuk Keluarga Miskin di Kabupaten Banyumas. Jurnal Sosiohumaniora, Vol 13, No. 2, Juli 2011. LPPM Unpad Bandung.

Moleong, LJ. 2014. Metodologi Penelitian Kualitatif. Edisi Revisi. Bandung: Remaja Rosdakarya.

Nugraha. 2009. Perancangan Sistem Informasi Administrasi Kependudukan (SIAK) sebagai Pengembangan e-Government Menuju Good Governance. Fakultas Pendidikan dan Ilmu Pengetahuan Alam UPI Bandung.

Parson, W. 2005. Public Policy : Pengantar Teori dan Praktik Analisis Kebijakan. Jakarta: Prenada Media.

Rachmawati, I. 2012. Pengaruh Pengembangan Sumber daya Aparatur Terhadap Efektivitas Pelayanan Administrasi Kependudukan Di Kabupaten Cianjur. Bandung: Program Doktor Ilmu Sosial Pascasarjana Universitas Padjadjaran.

Saefullah, A.D. 2008. Pemikiran Kontreporer Administrasi Publik, Prespektif Manajemen Sumber Daya Manusia Dalam Era Desentralisasi. Bandung: LP3AN FISIP UNPAD.

Sugiyono, 2008. Metode Penelitian Administrasi, Bandung: Alfabet.

Sumodiningrat, G. 1999. Pemberdayaan Masyarakat \& Jaring Pengaman Sosial (JPS). Jakarta: Gramedia Pustaka Utama.

Tachjan. 2008. Implementasi Kebijakan Publik. Cetakan ke II. Bandung: AIPI Bandung dan Puslit KP2W Lemlit Unpad.

Thoha, M. 2008. Ilmu Administrasi Publik Kontemporer. Jakarta: Prenada Media Press.

Undang-Undang Dasar Republik Indonesia Tahun 1945.

Undang-Undang Nomor 32 Tahun 2004 tentang Pemerintahan Daerah

Undang-Undang Nomor 23 Tahun 2006 tentang Administrasi Kependudukan.

Undang-Undang Nomor 24 Tahun 2013 Tentang Perubahan atas Undang-Undang Nomor 23 Tahun 2006 tentang Administrasi Kependudukan.

Peraturan Presiden Nomor 26 Tahun 2009 tentang Penerapan Kartu Tanda Penduduk (KTP) Ber- 
basis Nomor Induk Kependudukan (NIK), sebagaimana telah diubah dengan Peraturan Pemerintah Nomor 34 tahun 2010.

Peraturan Menteri Dalam Negeri Nomor 28 Tahun 2005 tentang Pedoman Penyelenggaraan Pendaftaran Penduduk dan Pencatatan Sipil di Daerah.

Peraturan Menteri Dalam Negeri Nomor 69 Tahun 2012 tentang Perubahan Atas Peraturan Menteri Dalam Negeri Nomor 52 Tahun 2008 tentang Standar Pelayanan Minimal Bidang Permerintahan Dalam Negeri di Kabupaten/Kota.
Peraturan Daerah Kabupaten Bandung Barat Nomor 15 Tahun 2011 Tentang Tata Cara Penyelenggaraan Administrasi Kependudukan

Indonesia dalam Angka. 2001. Badan Pusat Statistik Nasional.

Indonesia dalam Angka. 2003. Badan Pusat Statisitik Nasional 